\title{
IMPROVING THE PROPERTIES OF MILD STEEL BY TERNARY MULTILAYER COMPOSITE COATING VIA ELECTRODEPOSITION ROUTE
}

\author{
O.S.I. Fayomi ${ }^{1,2^{*}}$ A.P.I. Popoola ${ }^{1}$ and T. Monyai ${ }^{1}$ \\ ${ }^{1}$ Department of Chemical, Metallurgical and Materials Engineering, Tshwane University of \\ Technology, P.M.B. X680, Pretoria, South Africa \\ ${ }^{2}$ Department of Mechanical Engineering Covenant University, Ota, Ogun State, Nigeria
}

(Received December 15, 2014; revised July 14, 2016)

\begin{abstract}
A wide range of metal-oxides exhibit fascinating properties and multiple functionalities that could address challenge of physical and mechanical deterioration of materials in service. In this study, $\mathrm{Zn}-\mathrm{ZrO}{ }_{2}, \mathrm{Zn}-\mathrm{SiC}$ and $\mathrm{Zn}-\mathrm{ZrO}_{2}-\mathrm{SiC}$ composite coating was fabricated from zinc based sulphate electrolyte at constant current density, depth of immersion, distance between anode and cathode with time of deposition. The effect of particle on the physical behaviour of the coating was examined by coating gauge tester for the coating thickness and coating texture. The mechanical properties in term of hardness and wear characteristics were examined using high diamond micro-hardness tester and three body abrasive MTR-300 testers with dry sand rubber wheel apparatus with $5 \mathrm{~N}$ and $15 \mathrm{~N}$, respectively. The coating stability in harsh region was examined with isothermal furnace at $200{ }^{\circ} \mathrm{C}$ for $4 \mathrm{~h}$. The structural behaviour was investigated using scanning electron microscope attached with energy dispersion spectroscopy (SEM/EDS). The result shows that significant improvements in wear and hardness properties are linked to the microstructural modification of the coating as a result of the embedded particulate. The strengthening behaviour was improved with about $98 \%$ of coating efficiency. The progression of the coating thickness and texture were in line with other results obtained.
\end{abstract}

KEY WORDS: Microstructure, Strengthening effect, Mechanical properties, Co-deposition, $\mathrm{Zn}_{-} \mathrm{ZrO}_{2}-\mathrm{SiC}$

\section{INTRODUCTION}

Protective coatings are perhaps the most extensively used system for chemical and mechanical degradation in application. They are used to provide long-term protection under a broad range of corrosive environments, ranging from atmospheric contact to the most demanding chemical processing conditions. Protective coatings in themselves provide little or no structural strength, yet they protect other materials to preserve their strength and integrity [1-3]. Isolation of structural activeness of protective coating also gives proactive resistance against environmental corrosiveness. Though, surface coatings must provide a continuous barrier to a substrate, and any imperfection can become the focal point for degradation and corrosion of the substrate if not carefully fabricated [4-6]. The quality of a coating depends on many factors besides the nature of the materials involved. Coating and metal finishing operations are intended to increase corrosion or abrasion resistance, alter appearance, serve as an improved base for the adhesion of other materials, enhance wear and frictional characteristics, add hardness and improve electrical properties [7-9]. Surface coating is believed to be an engineering solution for enhancement of surfaces counter to wear, corrosion degradation and other surface linked occurrences.

In line with study investigated by [10-11] microstructural modification is strongly affected by the degree of addition and the kind of particles incorporated. Deposition as a result of super saturated deposit causes agglomeration which leads to the production of harder and more resistant coatings [12]. Zirconium addition had been reportedly to enhance the formation of $\mathrm{Ni}^{+}$ and $\mathrm{Zn}^{2+}$ ion during binary deposition. $\mathrm{SiC}$, are particulate with natural hard with constituent of $\mathrm{Si}$ and $\mathrm{C}$ [13]. The choice of the $\mathrm{Zn}-\mathrm{ZrO}_{2}-\mathrm{SiC}$ for electrodeposition was based on the fact that the synergistic codeposition of $\mathrm{ZrO}_{2}$ and $\mathrm{SiC}$ in $\mathrm{Zn}$ interface will guarantee a possible mechanical and electrochemical resistance bond needful during application.

*Corresponding author. E-mail: ojosundayfayomi3@gmail.com 
The anti-wear properties of the deposited layer were study with dry abrasive wear machine, and their hardness response by diamond base micro-hardness tester. The structural properties were examined using AFM, SEM/EDX.

\section{EXPERIMENTAL}

\section{Preparation of the substrates}

A flat sheet mild steel $(20 \mathrm{~mm}$ x $30 \mathrm{~mm})$ substrate was used in this study. The spectrochemical analysis is given in Table 1. Other materials employed for the purpose of this work include pure zinc plate anode, zinc sulfate, glycine, thiourea, $\mathrm{SiC}$ (45 nm, 97\% purity) and zirconium IV oxide ( $25 \mathrm{~nm}, 99.7 \%$ purity) was purchased from Sigma, South Africa. The initial surface preparation was performed with the fine grade of emery paper, properly cleaned with sodium carbonate, descaled/pickled and activated with $10 \% \mathrm{HCl}$ at ambient temperature for 10 second then followed by instant rinsing in deionized water.

Table 1. Nominal chemical composition (wt $\%$ ) of mild steel substrate.

\begin{tabular}{|l|c|c|c|c|c|c|c|c|}
\hline Element & $\mathrm{C}$ & $\mathrm{Mn}$ & $\mathrm{Si}$ & $\mathrm{P}$ & $\mathrm{S}$ & $\mathrm{Al}$ & $\mathrm{Ni}$ & $\mathrm{Fe}$ \\
\hline \% composition & 0.15 & 0.45 & 0.18 & 0.01 & 0.031 & 0.005 & 0.008 & 99.16 \\
\hline
\end{tabular}

Composition and formulation of the coating bath

The electro-deposition processing of $\mathrm{Zn}-\mathrm{ZrO}_{2}-\mathrm{SiC}$ composition alloy was performed in a single cell containing three electrodes (two anodes and one cathode). Zinc plates were used as anodes and the mild steel samples as a cathode. All chemical used were analytical grade and de-ionized water was used in all processes to prepare the plating solution. The bath composition admixed used for the coating is shown in Table 2. Table 3 shows the formulated $\mathrm{Zn}-\mathrm{ZrO}_{2}-\mathrm{SiC}$ aggregates for the coating bath formulation.

Table 2. $\mathrm{Zn}-\mathrm{ZrO}_{2}-\mathrm{SiC}$ sulphates bath formulation and plating parameters.

\begin{tabular}{|l|l|}
\hline Composition & Mass concentration $\mathrm{g} / \mathrm{L}$ \\
\hline $\mathrm{NaSO}_{4}$ & 30 \\
\hline Thiourea & 10 \\
\hline Boric acid & 10 \\
\hline $\mathrm{ZrO}_{2}$ & 10 \\
\hline $\mathrm{SiC}$ & 10 \\
\hline $\mathrm{ZnSO}$ & \\
\hline $\mathrm{pH}$ & 75 \\
\hline Current density & 5.0 \\
\hline Time & $2.0 \mathrm{~A} / \mathrm{cm}^{2}$ \\
\hline Temperature & $10 \mathrm{~min}$ \\
\hline Stirring rate & $40{ }^{\circ} \mathrm{C}$ \\
\hline
\end{tabular}

Table 3. Formulated designed bath composition of $\mathrm{Zn}-\mathrm{ZrO}_{2}-\mathrm{SiC}$ deposited at $10 \mathrm{~min}$.

\begin{tabular}{|c|c|c|}
\hline Sample order & Matrix sample & Current density $\left(\mathrm{A} / \mathrm{cm}^{2}\right)$ \\
\hline 1 & $\mathrm{Zn}-10 \mathrm{~g} \mathrm{ZrO}_{2}$ & 2.0 \\
\hline 2 & $\mathrm{Zn}-10 \mathrm{~g} \mathrm{SiC}$ & 2.0 \\
\hline 3 & $\mathrm{Zn}-10 \mathrm{~g} \mathrm{ZrO}-10 \mathrm{~g} \mathrm{SiC}$ & 2.0 \\
\hline
\end{tabular}

The samples were polished using a SiC grinding paper $1200 \mu \mathrm{m}$. After the surface preparation had completed, the samples were dipped in $\mathrm{HCl}$ for $10 \mathrm{~s}$ for good adhesion 
properties and cleaned with distilled water. Cathode and anodes were connected to the DC power supply through the rectifier. Electrodeposition was carried out with varying current density of $2.0 \mathrm{~A} / \mathrm{cm}^{2}$ for $10 \mathrm{~min}$. The plating bath was continuously stirred at $200 \mathrm{rpm}$ by magnetic stirrer for $2 \mathrm{~h}$. Then the samples were rinsed again with distilled water and left to dry out.

\section{Characterization of the deposited coatings}

The microstructural evolution and elemental analysis of the sectioned of the fabricated coatings samples were verified using VEGA 3 TESCAN scanning electron microscope with an attached energy dispersive spectrometer (SEM/EDS). The adhesion profiles, topography coatings, were observed with the help of Atomic Force microscopy (AFM). High optic diamond based durascan microhardness tester was used to estimate the average microhardness of the deposit in equal interval range with a load of $100 \mathrm{~g}$ for a period of $20 \mathrm{~s}$. The average microhardness trend was measured across the coating interface in an interval of $20 \mathrm{~m}$ using screw gauge attached to the Dura hardness tester.

Isothermal heat treatment (direct fired furnace atmosphere) of $\mathrm{Zn}-\mathrm{ZrO}_{2}-\mathrm{SiC}$ composite coating was carried out at $200{ }^{\circ} \mathrm{C}$ for $4 \mathrm{~h}$ to check the mechanical stability of the coated samples.

MTR 300 three body dry abrasive wear tests were performed on an ASTM-G65-04 dry sand rubber wheel apparatus. Silica sand procured from wear tech South Africa with a particle size between 300 and $600 \mu \mathrm{m}$ was used as the abrasive material and set to a flow rate of $7.89 \mathrm{~g} / \mathrm{s}$. An applied load of $5 \mathrm{~N}$ and $15 \mathrm{~N}$ with a rotational wheel speed of $150 \mathrm{rpm}$ were used. All samples were abraded for 5 min to evaluate the wear loss. The samples were embedded in epoxy resin leaving a working area of $0.785 \mathrm{~cm}^{2}$. The working surface was ground with grinding papers from 600 to 1000 grit, cleaned with distilled water and ethanol.

A conventional three electrode cell, consisting of $\mathrm{Ag} / \mathrm{AgCl}$, platinum and coated mild steel was used as: reference, counter and working electrodes, respectively. The electrochemical measurement was done with Autolab PGSTAT 101 Metrohm potentiostat/galvanostat. An electrolytic cell containing $50 \mathrm{~mL}$ of $3.65 \% \mathrm{NaCl}$ solution, with plated sample, a platinum which works as counter electrode and $\mathrm{Ag} / \mathrm{AgCl}$ as reference electrode were used. The potentiodynamic potential scan was fixed from $-1.5 \mathrm{~V}$ to $+1.5 \mathrm{mV}$ with scan rate of $0.012 \mathrm{~V} / \mathrm{s}$. The electrochemical corrosion test was performed at room temperature in a static solution

\section{RESULT AND DISCUSSIONS}

\section{Physical and mechanical behaviour of the fabricated coatings}

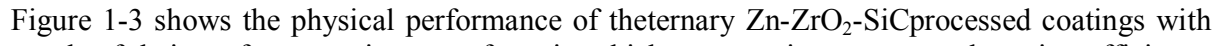
trends of their performance in term of coating thickness, coating texture and coating efficiency at constant deposition time and current density. From Figure 1, the influence of additive was seen as a major factor for the change in coating thickness. $\mathrm{Zn}-\mathrm{ZrO}_{2}$ possesses lower coating thickness in the series with $192 \mu \mathrm{m}$ comapre to the $\mathrm{Zn}$-SiC coating with $199 \mu \mathrm{m}$. Higher coating thickness of about $250.2 \mu \mathrm{m}$ was obatined with the ternary series $\mathrm{Zn}-\mathrm{ZrO}_{2}-\mathrm{SiC}$. From obervation, several reasons might have influence this characteristics reason been that process parameter goes along way to determine the extent of deposits in coating. The degree of embedded particulate in bath most time does not translate also into the amount or proportion of coating that ought to be deposited at the sbstract. Though, [11, 12] attested that coating with excellent properties are dependent on the stability of particulate dispersion in the chemical bath rather than the coating thickness. However from this study, the coating thickness was proportional to the degree of dispersion. 
In Figure 2, the activities of the coating was found to be in reverse order of the coating thickness. Good texture with ternary series alloy possess $105 \mu \mathrm{m}$ compare to the $\mathrm{Zn}-\mathrm{ZrO}_{2}$ and $\mathrm{Zn}-\mathrm{SiC}$ of $120 \mu \mathrm{m}$ and $135 \mu \mathrm{m}$ coating, respectively, which is in aggrement with the assertion that good coating most time has lower texture capacity due to better surface adhension.

The coating efficiency of the three series alloy in Figure 3 can be seen with excellent performance. Interestingly, all coatings displayed significant increase in coating thickness with coating efficiency as a function of the characteristics of individual additives. Although it is good to mention that structure of the surfaces come in different form especially during precipitation $[6,14]$. Some causes severe agglomeration resulting into unlimited plateau formation, uneven layer of film morphology with continuous valley. All these characters engender build up in coating performance and trend observed especially for $\mathrm{Zn}-\mathrm{ZrO}_{2}-\mathrm{SiC}$ processed coatings with $99.8 \%$ coating efficiency.

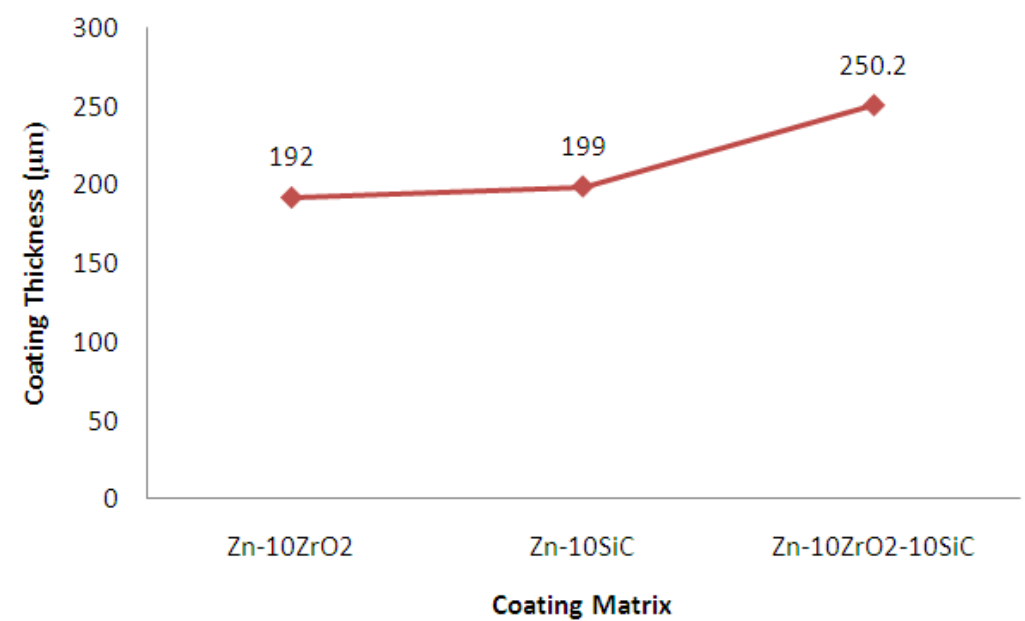

Figure 1. Coating thickness evaluation of deposited alloy.

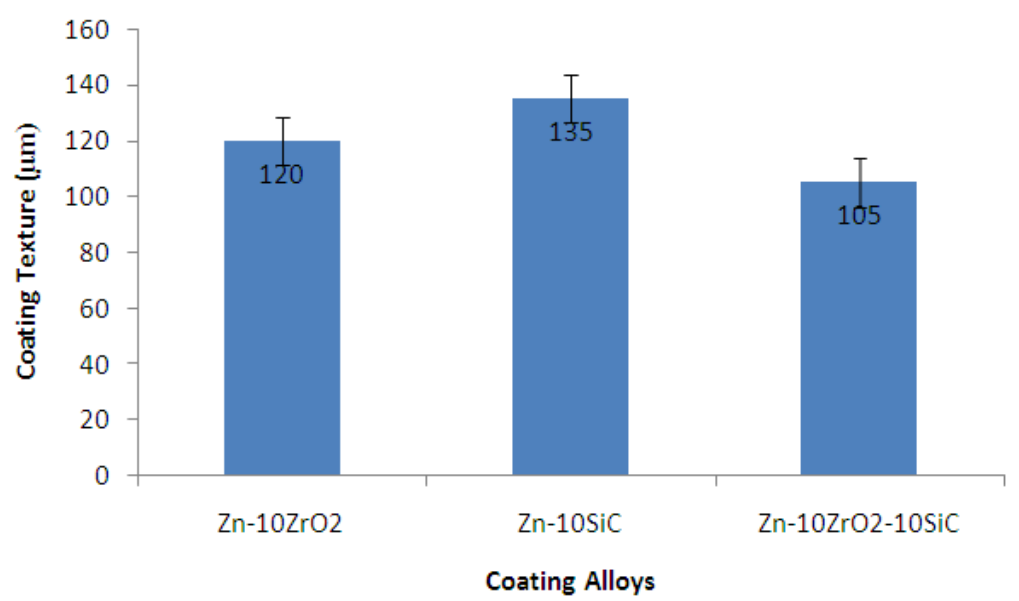

Figure 2. Coating texture evaluation of deposited alloy.

Bull. Chem. Soc. Ethiop. 2016, 30(3) 


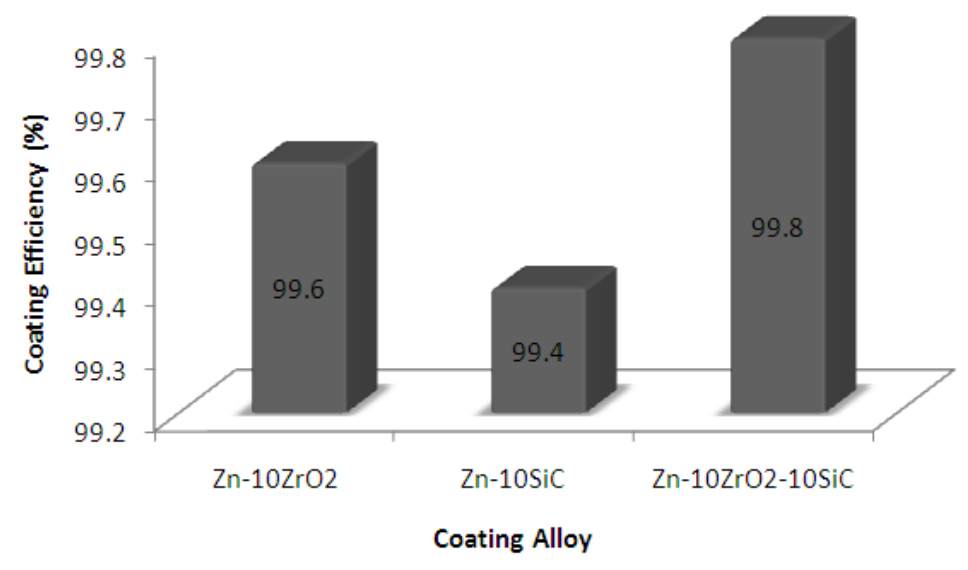

Figure 3. Coating efficiency of deposited alloy.

Figure 4 shows the micro-hardness comparative study of the steel substrate and the codeposited coating admixed at different matrix. There was a significant gain in microhardness value with ternary deposit of about $240 \mathrm{HVN}$. The trend follow $\mathrm{Zn}-\mathrm{ZrO}_{2}$ deposit with $240 \mathrm{HVN}$ compare to the as-received substrate of $143 \mathrm{HVN}$. It is noteworthy to see the impact of the deposit on the properties of the coating. Though this is expected reason had been that increase in the hardness value are often attributed to the particle inclusion in the $\mathrm{Zn}$ matrix [4, 7] which helps in the built-up of adhered thin crystal. Multilayer crystal visible at the interfaces in either heterogeneous or homogeneous nature as a result of agglomeration or stable precipitation cause significant changes in hardness characteristics.

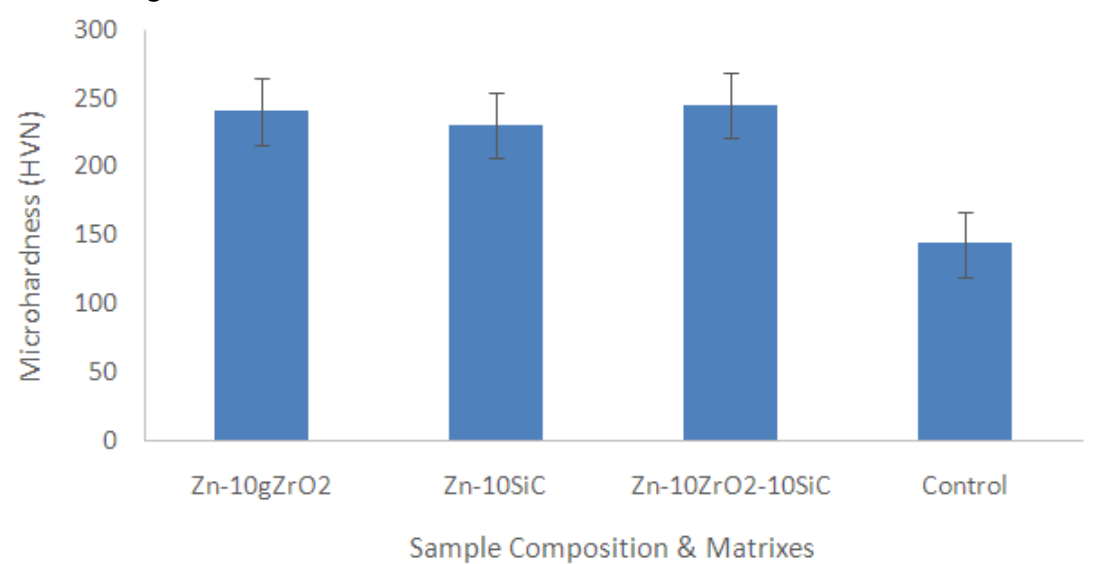

Figure 4. Micro-hardness of deposited composite coatings before heat treatment.

More over weight fraction or concentration of particulate are also adjusted to contribute tremendously to the degree of hardness propagation [13]. This assertion was found true in respect to $\mathrm{Zn}-\mathrm{SiC}-\mathrm{ZrO}_{2}$ content into the metal lattices resulted into solid structure thereby forming a suitable adhesion and enhancement of hardness properties. Comparison of the deposits shows that the irregularities of the particle embedded at the metal/film interface of the 
binary phase of $\mathrm{SiC}$ and $\mathrm{ZrO}_{2}$ results to a reduction in the hardness value compare to the ternary phase which is in line with study by $[7,10]$.

Figure 5 shows the thermo-mechanical characteristics of the deposited alloy at $200{ }^{\circ} \mathrm{C}$ in $4 \mathrm{~h}$ with isothermal furnace route. The microhardness comparative study indicated an improved recrystallization especially for the $\mathrm{Zn}-\mathrm{ZrO}_{2}-\mathrm{SiC}$ processed coatings. Although the behaviour of this deposited alloy at different fabricated coatings still gain significant improvement above the as-received sample with over $60 \%$ deterioration. The slight depreciation might be due to little agglomeration during precipitation which often cause pilled ups of thin films and secondly the unseen voids from the microstructural phase as a results of adhesion. One major gain in this thermal process as it is expected to give a possible relieve of stress in term grain restructuring and expose the infringement of hydrogen embrittlement from initial stage of coating [13] which could either improve or reduces the micro-hardness property as seen in Figure 5.

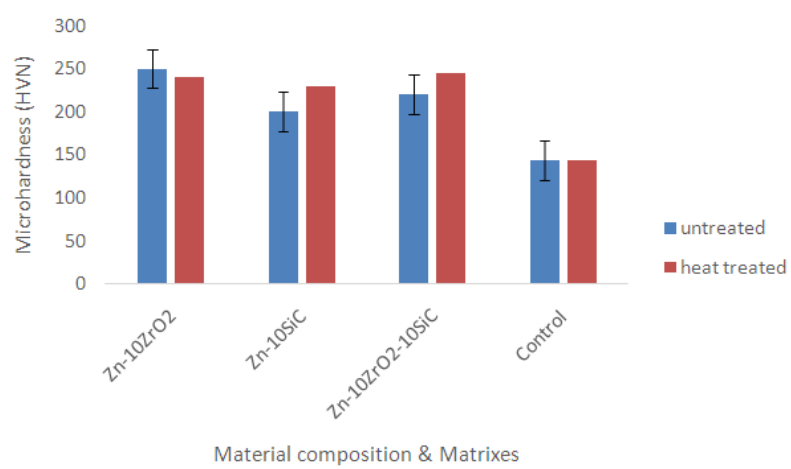

Figure 5. Comparative micro-hardness trend of deposited composite coatings prior and after heat treatment at $200{ }^{\circ} \mathrm{C}$.

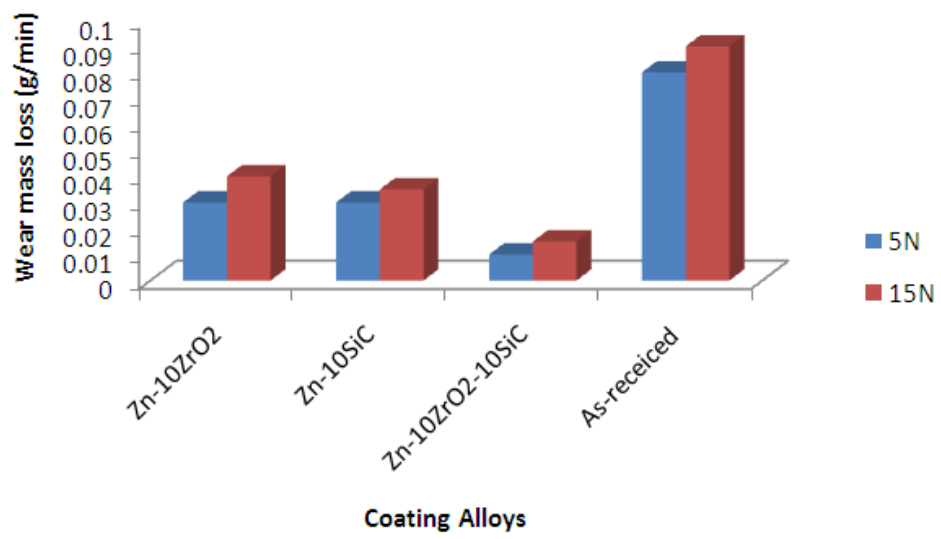

Figure 6. Wear deformation response of the deposited coatings.

The wear loss characteristics of $\mathrm{Zn}-\mathrm{ZrO}_{2}-\mathrm{SiC}$ and its binary alloys on dry abrasive tester in $5 \mathrm{~N}$ and $15 \mathrm{~N}$ force are presented in Figure 6 . From all indication, wear loss is very high for the as-received sample with about $0.08 \mathrm{~g} / \mathrm{min}$ and $0.09 \mathrm{~g} / \mathrm{min}$ for $\%$ and $15 \mathrm{~N}$, respectively. $\mathrm{Zn}-$ $\mathrm{ZrO}_{2}-\mathrm{SiC}$ possesses good wear resistance performance of $0.01 \mathrm{~g} / \mathrm{min}$ and $0.015 \mathrm{~g} / \mathrm{min}$ for the two force applied. As against the binary series alloy $\mathrm{Zn}-\mathrm{SiC}$ and $\mathrm{Zn}-\mathrm{ZrO}_{2}$ a wear mass loss of 
$0.03-0.04 \mathrm{~g} / \mathrm{min}$ and $0.03 \mathrm{~g} / \mathrm{min}$ and $0.035 \mathrm{~g} / \mathrm{min}$ was attained. This great influence by the ternary incorporated coatings may be attributed to the high multifaceted contribution of the particles in the conditioning bath [4, 8]. More so, structural properties developed by the $\mathrm{Zn}$ $\mathrm{ZrO}_{2}-\mathrm{SiC}$ could be seen to strengthening the adhesion properties to retard massive plastic dislocation seen in Figure 6. Though, significant result by [6] affirmed that stable adhesion and solid reinforcement could alter positively the compatibility of the coatings by reducing possible scaling and increased the wear impunity into the steel.

\section{Structural study}

Figure 7a-d presents the structural change of as-received mild steel and series of deposited coating as results of particulate embedded. All deposited coating shows good and preferred homogeneous coatings with fine crystals circular ridges and pronounced equigranular structure. The formation of crystalline growth was seen with $\mathrm{Zn}-\mathrm{ZrO}_{2}$ and $\mathrm{Zn}-\mathrm{SiC}$ which might be traced to the effect of $\mathrm{Zr}$ and $\mathrm{Si}$ metal in the deposit since metal matrix composite of $\mathrm{ZrO}_{2}$ and $\mathrm{SiC}$ constitute formidable metal grain from it composite matrix.
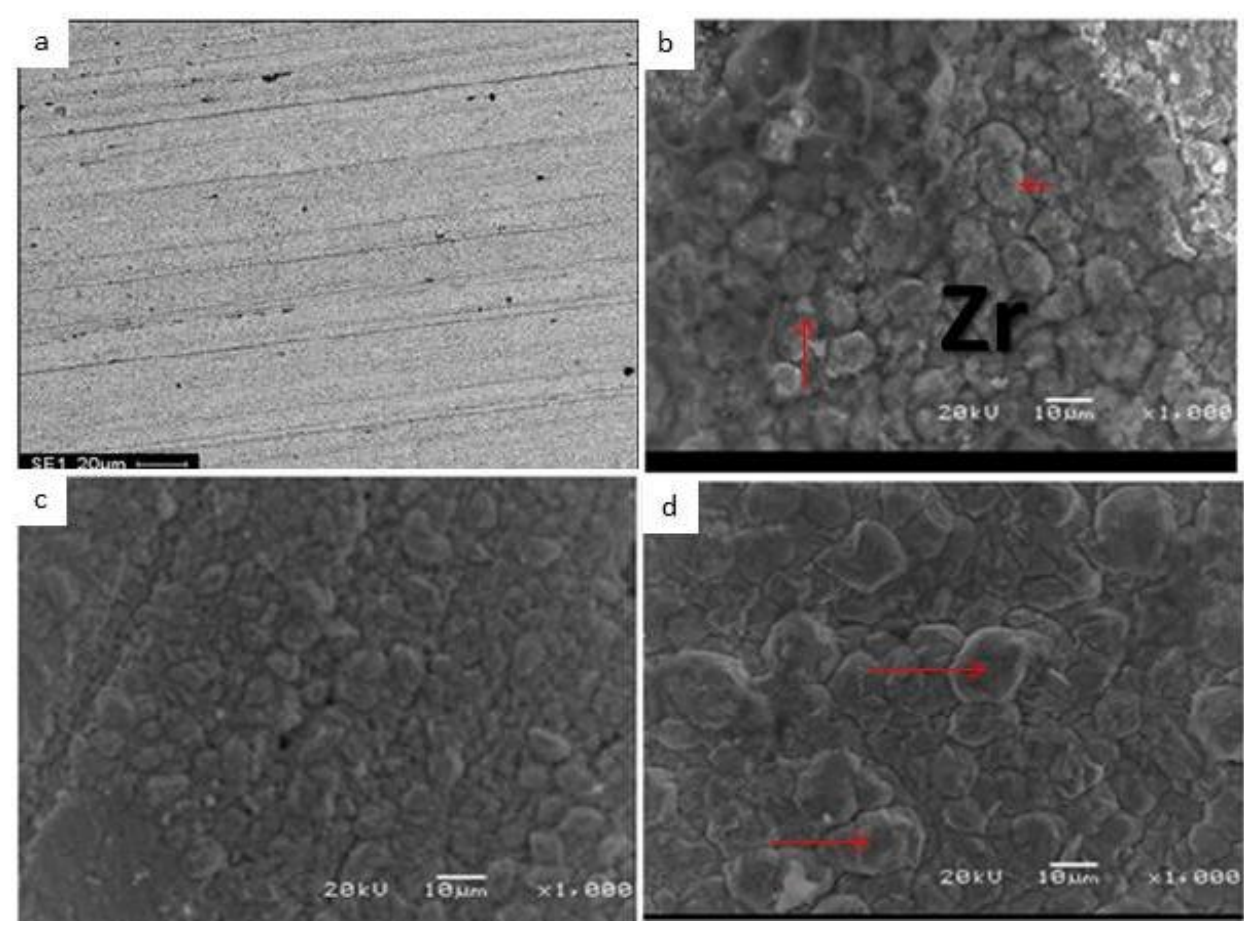

Figure 7. SEM morphology of a) as-received samples, b) $\mathrm{Zn}-\mathrm{ZrO}_{2}$, c) $\mathrm{Zn}-\mathrm{SiC}$ and d) $\mathrm{Zn}-\mathrm{ZrO}_{2}-$ $\mathrm{SiC}$ at $2 \mathrm{~A} / \mathrm{cm}^{2}$.

Moreover, studies by $[8,13]$ also attested that formation of crystalline particulates of zinc silicate exists higher than $1 \mu \mathrm{m}$ from $\mathrm{ZnO}$ matrix by Si participation in the bath. More of spherical patches overlapping with nodular were seen with in $\mathrm{Zn}-\mathrm{ZrO}_{2}$. With $\mathrm{Zn}-\mathrm{ZrO}_{2}-\mathrm{SiC}$ in $7 \mathrm{~d}$ the microstructural evolution was apparently formidable, clear and sequence in term of crystal 
development. There are no visible heterogeneous phases seen due to perfect blend of the individual composite particulate.

However, it is vital to remark that miscible metal grain promote strengthening characteristic often than when compare to single alloy matrixes which is in line with the obtained results by [12-13] that particle agglomeration occurs when greater attraction than repulsion energy exists between them. Solid agglomerate is seen to occur with $\mathrm{Zn} / \mathrm{Zr} / \mathrm{Si}$ matrix thereby providing an interfacial precipitation on steel.

\section{CONCLUSION}

The deposition of $\mathrm{Zn}-\mathrm{ZrO}_{2} / \mathrm{SiC}$ composite coating on mild steel was successful owning to the strengthening characteristics of $\mathrm{ZrO}_{2} / \mathrm{SiC}$ nanoparticles in the deposition bath. The crystal growth was found to significantly influence positively the physical and mechanical behaviour of the coatings. Interestingly up to $99.8 \%$ coating efficiency were obtained. The response of wear degradation and thermal deformation was very minimal as a result of the adhered nature of the fabricated coating.

\section{ACKNOWLEDGEMENTS}

This material is based upon the work supported financially by National Research Foundation, South Africa. Surface Engineering Research Centre (SERC), Tshwane University of Technology Pretoria, South Africa is appreciated for the provision of laboratory facilities and technical advice.

\section{REFERENCES}

1. Mohamed, Y.H.; Ahmadand, H.; Adel, M.A. Int. J. Electrochem. Sci. 2014, 9, 1942.

2. Solomon, M.M.; Umoren, S.A.; Udosoro, I.I.; Udoh, A.P. Corr. Sci. 2010, 52, 1317.

3. Fayomi, O.S. I.; Popoola, A.P.I. Res. Chem. Int. 2013, 39, 1313.

4. Zanella, C.; Lekka, M.; Bonora, P.L. J. Appl. Electrochem. 2009, 39, 31.

5. Kuo, S.L.; Chen, Y.C.; Ger, M.D.; Hwu, W.H. Mater. Chem. Phys. 2004, 86, 5.

6. Fayomi, O.S.I.; Popoola, A.P.I.; Inegbenebor, A.O. Results in Physics 2014, 4,79.

7. Krishnaveni, K.; Narayanan, T.S.; Seshadr, S.K. J. Alloys Comp. 2008, 466, 412.

8. Gyftou, P.; Pavlatou, E.A.; Spyrellis, N. Appl. Surf. Sci. 2008, 254, 5910.

9. Sohrabi, A.; Dolati, A.; Ghorbani, M.; Monfared, A.; Stroeve, P. Mat. Chem. Phys. 2010, $121,497$.

10. Rusu, D.E.; Ispas, A.; Bund, A.; Gheorghies, C.; Cara, G. J. Coating Techn. Res. 2012, 9, 87.

11. Rami, M.; Benamar, E.; Fahoume, M.; Chraibia, F.; Ennaoui, A. Physi. Soc.2000, 3, 66.

12. Fayomi, O.S.I.; Abdulwahab, M.; Popoola, A.P.I. J Ovonic. Res. 2013, 9, 123.

13. Fayomi, O.S.I.; Popoola, A.P.I. Egyptian J. Basic App. Sci. 2014, 4, 1.

14. Allan, E.M.; James, B.K.; Harold, M.F. J. Chem. Eng. Data 2008, 6, 596. 